\title{
OPTIMASI PEMASANGAN KAPASITOR PADA SISTEM JARINGAN LISTRIK DISTRIBUSI DI BALI MENGGUNAKAN METODE QUANTUM GENETIC ALGORITHM
}

\author{
Maria Gusti Agung Ayu Permata, Antonius Ibi Weking*, Widyadi Setiawan \\ Jurusan Teknik Elektro, Fakultas Teknik Universitas Udayana \\ Email: *tony@unud.ac.id
}

\begin{abstract}
Abstrak
Penelitian ini melakukan optimasi pemasangan kapasitor pada sistem jaringan listrik distribusi di Penyulang Penyabangan, Singaraja, Bali menggunakan metode Quantum Genetic Algorithm untuk mengurangi dampak dari meningkatnya arus reaktif. Penyulang ini, terdiri dari 162 bus di mana 62 bus yang langsung terhubung ke beban dan 5 bus diantaranya terhubung dengan konsumen tegangan menengah. Hasil dari penelitian ini didapatkan besar kapasitas kapasitor yang terpasang di 31 bus yang memiliki nilai faktor daya kurang dari batas yang diizinkan dan nilai rugirugi daya menurun dari sebesar 0,0674 MW dan 0,0546 MVAr menjadi sebesar 0,0543 MW dan 0,0442 MVAr.
\end{abstract}

Kata Kunci : Kapasitor, Rugi-rugi Daya, Faktor Daya, Quantum Genetic Algorithm.

\section{Abstract}

This study optimized the installation of capacitors on the distribution grid system in Penyabangan feeder, Singaraja, Bali using the Quantum Genetic Algorithm method to reduce the impact of increasing reactive currents. This feeder, consisting of 162 buses in which 62 buses are directly connected to the load and 5 buses are connected to medium voltage cosumers. The results of this study are obtained by the capacity of capacitors installed in 31 buses that have a power factor value less than the permitted limit and the power loss values decrease from 0,0674 MW and 0,0546 MVAr to 0,0543 MW and 0,0442 MVAr.

Keywords : Capacitors, Power Losses, Power Factors, Quantum Genetic Algorithm.

\section{PENDAHULUAN}

Energi listrik digunakan untuk memenuhi kebutuhan sehari-hari seperti penerangan, pemanas, hiburan, dan beraneka ragam peralatan listrik (beban) yang digunakan lainnya. Melihat bagaimana pentingnya energi listrik, maka kebutuhan listrik terus meningkat dari tahun ke tahun. Peningkatan ini diikuti dengan peningkatan permintaan suplai daya reaktif akibat beban yang bersifat induktif meningkat. Contoh beban yang bersifat induktif adalah trafo pada rectifier, lampu TL, dan motor induksi (AC). Beban yang bersifat induktif membutuhkan daya reaktif. Jika suatu sistem jaringan tidak memiliki sumber daya reaktif di daerah sekitar beban, semua kebutuhan beban reaktif akan dipikul oleh generator. Hal ini menyebabkan mengalirnya arus reaktif pada jaringan yang mengakibatkan terjadinya penurunan faktor daya, jatuh tegangan dan besarnya rugi-rugi daya. Pemasangan kapasitor merupakan salah satu cara untuk mengurangi dampak dari meningkatnya arus reaktif. [1]

Pemasangan kapasitor pada jaringan listrik distribusi yang besar sangatlah sulit karena perlunya mengetahui seberapa besar kapasitas kapasitor yang tepat agar dapat memperbaiki faktor daya dan mengurangi rugi-rugi daya. Oleh karena itu, dilakukan penelitian menggunakan metode Quantum Genetic Algorithm (QGA) untuk memperbaiki faktor daya dan mengurangi rugi-rugi daya. Pemilihan QGA sebagai metode yang digunakan karena QGA merupakan evolusi dari Algoritma Genetika yang dapat diterapkan pada berbagai masalah optimasi dan dapat memecahkan masalah optimasi kombinatorial.

Penelitian ini menggunakan data Penyulang Penyabangan, Singaraja, Bali Utara. Pada 
penyulang ini terdapat palguna, tambak dan sebagainya yang dapat menyebabkan terjadinya jatuh tegangan, penurunan faktor daya, dan besarnya rugi-rugi daya karena generator yang dimiliki telah rusak. Tujuan penelitian ini adalah untuk mengetahui besar kapasitas kapasitor yang maksimal untuk mendapatkan nilai faktor daya yang baik untuk kelistrikkan tersebut sehingga memperbaiki rugi-rugi daya pada jaringan.

\section{TINJAUAN PUSTAKA}

\subsection{Sistem Distribusi}

Sistem distribusi merupakan bagian dari sistem listrik yang berfungsi untuk menyalurkan atau mendistribusikan energi listrik antara sumber energi listrik yang berjumlah besar dengan switch pelanggan layanan. Berdasarkan bentuk jaringannya, sistem jaringan distribusi tenaga listrik terdiri dari jaringan distribusi sistem radial, jaringan disrtibusi sistem rangkaian tertutup (loop circuit), dan jaringan distribusi sistem spindel. [2] Pada penelitian ini digunakan penyulang penyabangan di mana sistem jaringan distribusinya adalah sistem radial. Pada penyulang ini masih terdapat bus berbeban yang faktor dayanya rendah.

\subsection{Faktor Daya}

Faktor daya atau power factor ( $p f$ atau cos $\theta$ ) adalah perbandingan antara daya aktif (Watt) dengan daya semu (VA). Dari gambar 1 , didapatkan persamaan daya aktif $(P)$, daya reaktif $(\mathrm{Q})$, dan daya semu (S) sebagai berikut di bawah ini. [3]

$$
\begin{aligned}
& S=\sqrt{P^{2}+Q^{2}} \\
& P=V I \cos \varphi \quad \text { (Watt) } \\
& Q=V I \sin \varphi(V A r) \\
& S=V I \quad(V A) \\
& \text { Faktor Daya }(P F)=\frac{P}{S}=\frac{W}{V A} \\
& \cos \theta=\mathrm{pf}=\frac{P}{S} \\
& \mathrm{P}=\text { Daya Aktif }(\mathrm{W}) \\
& \mathrm{Q}=\text { Daya Reaktif (VAr) } \\
& \mathrm{S}=\text { Daya Semu (VA) } \\
& \mathrm{V}=\text { Tegangan }(\mathrm{V}) \\
& \mathrm{I}=\operatorname{Arus}(\mathrm{A}) \\
& \varphi=\text { Sudut Fasa }\left({ }^{\circ}\right)
\end{aligned}
$$

Dengan mengasumsikan beban disuplai dengan daya aktif $(P)$, daya reaktif tertinggal
$\left(\mathrm{Q}_{1}\right)$ dan daya semu $\left(\mathrm{S}_{1}\right)$ pada faktor daya tertinggal bahwa: [4]

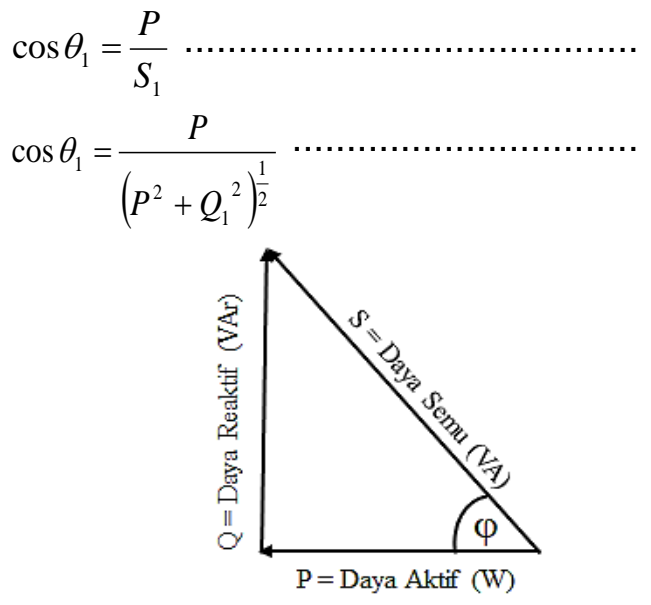

\section{Gambar 1 Segitia Daya}

Daya reaktif yang dikirimkan ke konsumen, tidak dimanfaatkan oleh konsumen. Jika penggunaan daya reaktif lebih besar dari total daya yang dikirimkan ke konsumen, sudut akan meningkat dan menghasilkan faktor daya yang lebih rendah dari yang diharapkan serta menurunkan efisiensi dari sistem distribusi ketenagalistrikan. Salah satu cara untuk memperbaiki faktor daya dengan dilakukannya pemasangan kapasitor. Kapasitor berfungsi sebagai pembangkit daya reaktif sehingga kebutuhan daya reaktif beban induktif dapat diperoleh dari kapasitor. [3] Kapasitor bank harus mempunyai daya $Q_{c}$ yang sama dengan daya reaktif dari sistem yang faktor dayanya akan diperbaiki. Besarnya daya reaktif yang diperlukan untuk mengubah faktor daya dari $\left(\cos \theta_{1}\right)$ menjadi $\left(\cos \theta_{2}\right)$ dapat ditentukan dengan : [5]

$Q_{C}=P \times\left(\tan \theta_{1}-\tan \theta_{2}\right)$

Di mana:

Qc = Kompensasi daya reaktif yang dibutuhkan (kVAr)

$\mathrm{P}=$ Daya aktif $(\mathrm{kW})$

$\cos \theta_{1}=$ faktor daya (pf) lama

$\cos \theta_{2}=$ faktor daya (pf) baru atau target

Ketika kapasitor bank dipasang secara paralel pada beban, maka nilai faktor daya yang baru $\left(\cos \theta_{2}\right)$ sebagai berikut di bawah ini: $\cos \theta_{2}=\frac{P}{S_{2}}$

$$
=\frac{P}{\left(P^{2}+Q^{2}\right)^{\frac{1}{2}}}=\frac{P}{\left(P^{2}+\left(Q_{1}-Q_{C}\right)^{2}\right)^{\frac{1}{2}}} \cdots
$$

Dari Gambar 2, dapat dilihat daya semu dan daya reaktif menurun dari daya semu pertama 
$\left(\mathrm{S}_{1}\right)$ kVA menjadi daya semu kedua $\left(\mathrm{S}_{2}\right)$ kVA dan dari $\mathrm{Q}_{1} \mathrm{kVAr}$ menjadi $\mathrm{Q}_{2} \mathrm{kVAr}$. [4]

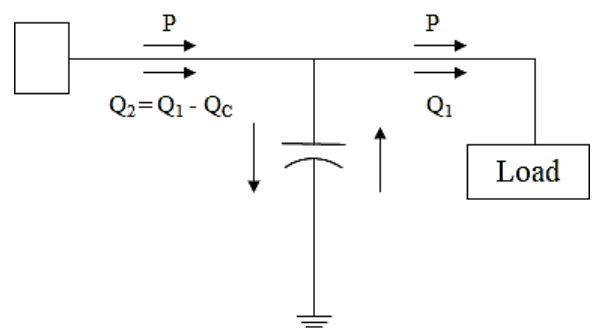

(a)

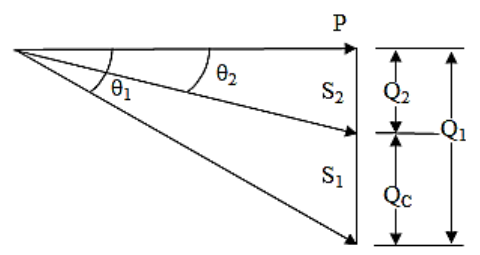

(b)

Gambar 2 llustrasi dari Koreksi Faktor Daya

\subsection{Bank Kapasitor}

Bank kapasitor adalah peralatan yang digunakan untuk memperbaiki kualitas pasokan energi listrik seperti memperbaiki mutu tegangan di sisi beban, memperbaiki faktor daya $(\cos \theta)$ dan mengurangi rugi-rugi transmisi. Efisiensi pada suatu jaringan akan meningkat dengan dipasangnya kapasitor shunt karena memperbaiki faktor daya. [6]

Jika kapasitor dihubungkan secara paralel pada saluran, maka kapasitor akan memberi arus reaktif untuk mengimbangi arus yang diambil oleh beban induktif. Kapasitor shunt akan memberikan arus leading dengan menghitung sebagian atau seluruh komponen lagging dari arus beban induktif pada tempat di mana kapasitor itu terpasang. [5]

\subsection{Metode Newton Raphson}

Meode ini digunakan untuk menghitung rugi dalam sistem serta menghitung tegangan pada masing-masing bus. Dalam menerapkan metode ini pada penyelesaian persamaan aliran beban dapat memilih untuk menyatakan tegangan-tegangan bus dan admitansiadmitansi saluran dalam bentuk polar. Persamaan tegangan bus dan admitasnsiadmitani saluran dalam bentuk polar sebagai berikut: [8]

$$
\begin{aligned}
& P_{k}-j Q_{k}=V_{k}^{*} \sum_{n=1}^{N} Y_{k n} V_{n} \\
& V_{k}=\left|V_{k}\right| \angle \delta_{k} \ldots \ldots \ldots \ldots \ldots \ldots \ldots
\end{aligned}
$$

$V_{n}=\left|V_{n}\right| \angle \delta_{n}$

$\left|Y_{k n}\right|=\left|Y_{k n}\right| \angle \theta_{k n}$

$P_{k}-j Q_{k}=\sum_{n \neq k}^{N} n=1\left|V_{k} V_{n} Y_{k n}\right|\left\langle\left(\theta_{k n}+\delta_{n}-\delta_{k}\right)\right.$

$Q_{k}=-\sum_{n \neq k}^{N} n=1\left|V_{k} V_{n} Y_{k n}\right| \sin \left(\theta_{k n}+\delta_{n}-\delta_{k}\right)$

$\Delta P_{k}=P_{k, \text { spec }}-P_{k, \text { calc }}$

$\Delta Q_{k}=Q_{k, \text { spec }}-Q_{k, \text { calc }}$

Di mana :

$\mathrm{P}_{\mathrm{k}}=$ Daya aktif pada suatu bus $\mathrm{k}$

$\mathrm{Q}_{\mathrm{k}}=$ Daya reaktif pada suatu bus $\mathrm{k}$

$\mathrm{V}_{\mathrm{k}}=$ Tegangan pada bus $\mathrm{k}$

$\mathrm{V}_{\mathrm{n}}=$ Tegangan pada bus $\mathrm{n}$

$\mathrm{Y}_{\mathrm{kn}}=$ Admitansi pada saluran bus $\mathrm{k}-\mathrm{n}$

$\delta_{\mathrm{n} / \mathrm{k}}=$ Sudut fasa tegangan pada bus $\mathrm{n} / \mathrm{k}$

\subsection{Quantum Genetic Algorithm}

Metode QGA adalah metode optimasi probabilistik berdasarkan komputasi kuantum, dikombinasikan dengan teori perhitungan kuantum dan teori algoritma genetika. Quantum Genetic Algorithm atau algoritma genetika kuantum (QGA) adalah algoritma evolusioner (EA) yang prinsipnya merupakan metode pencarian dan optimasi stokastik berdasarkan prinsip biologis alami.

QGA didasarkan pada konsep qubit dan superposisi keadaan mekanika kuantum. Pada komputasi kuantum, qubit atau quantum bit adalah unit dasar dari informasi kuantum. Sebuat qubit mungkin dapat berada dalam status ' 1 ', status ' 0 ', atau dalam keadaan koheren superposisi manapun dari keduanya disaat waktu bersamaan.

Pada umumnya, m-qubit direpresntasikan oleh vektor status superposisi dalam $2^{\mathrm{m}}$ dimensi. Persamaan status qubit dapat direpresentasikan sebagai berikut:

$|\psi\rangle=|\alpha|^{2}+|\beta|^{2}$

Di mana $\alpha$ dan $\beta$ merupakan amplitudo probabilitas atau bilangan kompleks yang digunakan dalam menggambarkan perilaku dari status tersebut, dan suatu status yang sesuai disebut amplifikasi amplitudo (amplitude amplification). Kondisi normalisasi dari status tersebut adalah sebagai berikut:

$|\alpha|^{2}+|\beta|^{2}=1$

$|\alpha|^{2}$ adalah probabilitas qubit dalam status

0 dan $|\beta|^{2}$ adalah probabilitas qubit berada dalam status 1 . Status qubit dapat dilihat pada 
Gambar 5. Satu qubit individu didefinisikan dengan sepasang angka $(\alpha, \beta)$ sebagai berikut : $\left[\begin{array}{l}\alpha \\ \beta\end{array}\right]$

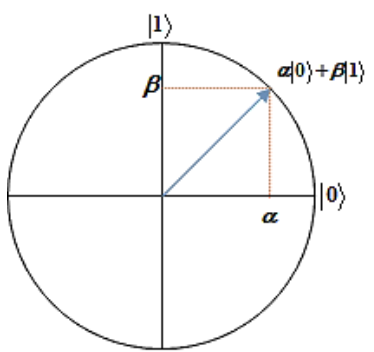

Gambar 5 Status Quantum Bit (Qubit)

Persamaan (21) merupakan karakteristik dari persamaan (19) dan (20). Satu qubit individu dengan panjang $m$ didefinisikan sebagai string qubit. Untuk merepresentasikan m-qubit didefinisikan sebagai berikut:

$\left[\begin{array}{c|c|c|c}\alpha_{1} & \alpha_{2} & \ldots & \alpha_{m} \\ \beta_{1} & \beta_{2} & \ldots & \beta_{m}\end{array}\right]$

Di mana, $\left|\alpha_{i}\right|^{2}+\left|\beta_{i}\right|^{2}=1, i=1,2,3, \ldots, m$. Represntasi ini memiliki keuntungan bahwa ia mampu mewakili status superposisi manapun.

Konvergensi atau keadaan menuju satu titik juga bisa diperoleh dengan representasi qubit. Artinya, representasi qubit mampu memiliki dua karakteristik eksplorasi dan eksploitasi secara bersamaan.[9]

\subsubsection{Gerbang Rotasi (Rotation Gate)}

Gerbang rotasi (Q-Gate) didefinisikan sebagai operator variasi QGA yang digunakan untuk mendapatkan qubit ( $\alpha$ dan $\beta$ ) yang baru dengan mengubah $\alpha$ dan $\beta$ yang lama. $\left|\alpha^{\prime}\right|^{2}+\left|\beta^{\prime}\right|^{2}=1$ dimana $\alpha^{\prime}$ dan $\beta^{\prime}$ adalah nilai qubit yang terbaru. Persamaan Q-Gate sebagai qubit yaitu:[9]

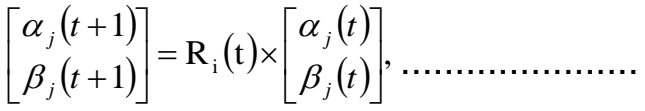

$$
\begin{aligned}
& (j=1,2, \ldots, n) \\
& \mathrm{R}_{\mathrm{i}}(\mathrm{t})=\left[\begin{array}{cc}
\cos \Delta \theta_{i} & -\sin \Delta \theta_{i} \\
\sin \Delta \theta_{i} & \cos \Delta \theta_{i}
\end{array}\right], \ldots \ldots \ldots \ldots \ldots \ldots \ldots \ldots \ldots \ldots \ldots \ldots \ldots \ldots \\
& (i=1,2, \ldots, n) \\
& \text { Di mana, } \\
& n \quad=\text { jumlah qubit di dalam individu qubit. } \\
& \mathbf{R}_{\mathbf{i}}(\mathbf{t})=\text { gerbang rotasi } . \\
& \Delta \theta_{i}=\text { sudut rotasi (Gambar 6) dari setiap } \\
& \text { anggota populasi (qubit). }
\end{aligned}
$$


Langkah-langkah kerja metode QGA dalam mengoptimalkan penempatan kapasitor untuk memperbesar nilai faktor daya sebagai berikut di bawah ini.

1. $t=0$, di mana $t$ adalah perhitungan generasi atau iterasi.

2. Inisilaisasi populasi dari anggota populasi (qubit string)

$U(0)=\left\{u_{1}(0), u_{2}(0), \ldots, u_{n}(0)\right\}$

Setiap string qubit diwakili sebagai berikut:

$$
\left.u_{1}(0)=\left[\begin{array}{ll}
\alpha_{1}(0) \\
\beta_{1}(0)
\end{array}\left|\begin{array}{ll}
\alpha_{2}(0) \\
\beta_{2}(0)
\end{array}\right| \cdots \mid \begin{array}{l}
\alpha_{m}(0) \\
\beta_{m}(0)
\end{array}\right]\right]
$$

3. Pada semua string qubit inisialisai amplifikasi amplitude dengan :

$$
u_{1}(0)=\left|\begin{array}{lll}
\frac{1}{\sqrt{2}} & \frac{1}{\sqrt{2}} & \ldots \\
\frac{1}{\sqrt{2}} & \frac{1}{\sqrt{2}} & \ldots
\end{array}\right|
$$

4. Buatlah secara acak sebuah solusi set biner $\mathrm{H}(0)$ dengan mengamati keadaan $\mathrm{U}(0)$ :

$H(0)=\left\{h_{1}(0), h_{2}(0), \ldots, h_{n}(0)\right\}$

Setiap lokasi kapasitor diwakili oleh bilangan biner 10 bit. 9 bit awal menunjukkan lokasi kapasitor yang akan dipasang, 1 bit lainnya menunjukkan kapasitas kapasitor yang akan dipasang.

5. Evaluasi setiap $h_{i}(0)(i=1,2, \ldots, n)$ dan siapkan matriks data bus.

6. Dengan menggunakan data bus, jalankan load flow dan dapatkan rugi-rugi daya dan nilai faktor daya.

7. Hitung fungsi objektif dan simpan nilai fitness.

8. Lakukan langkah (5) - (7) untuk setiap anggota populasi.

9. Temukan anggota populasi dengan nilai fungsi objektif tertinggi dan simpan sebagai pemenang iterasi.

10. Iterasi selanjutnya $(t=t+1)$.

11. Buat populasi berikutnya dari populasi saat ini dengan memutar masing-masing anggota sehingga generasi baru lebih dekat dengan pemenang. Lihat Gambar 6, rotasi dilakukan dengan matriks rotator yang dihitung dengan persamaan (20) dan (23).

12. Lakukan langkah 4-6 sebanyak yang dibutuhkan.

13. Solusi yang paling optimal adalah pemenang iterasi terakhir.

\subsection{Sistem Optimasi}

Optimasi adalah proses memaksimasi atau meminimasi suatu fungsi tujuan dengan tetap memperhatikan pembatas yang ada. Permasalahan optimasi dengan lebih dari satu fungsi tujuan disebut optimasi multitujuan (multiobjective).

Pada penelitian ini digunakan Penyulang Penyabangan, Singaraja, Bali Utara. Diagram Single line penyulang ini dapat dilihat pada Gambar 7. Sumber listrik penyulang ini berasal dari Trafo II / 10 MVA, Gardu induk Pemaron. Parameter yang diperlukan dalam penelitian ini adalah sebagai berikut:

- Data tegangan dan arus yang mengalir pada saluran.

- Data total daya yang dibangkitkan berupa daya aktif (MW) dan daya reaktif (MVAr) yang disuplai ke masing-masing bus.

- Data setiap beban.

Nilai kapasitas kapasitor berupa bilangan integer dengan nilai gen berisi 0,001 MVAr sampai 0,400 MVAr. Kromosom berisikan informasi besar kapasitas daya reaktif yang disuntikkan pada sistem bus. Pengujian nilai kromosom adalah fungsi objektif.

Fungsi objektif pada penelitian ini adalah meminimalisasi rugi-rugi daya dengan pemasangan kapasitor yang optimal. Persamaan fungsi objektif pada penelitian ini sebagai berikut:

Minimum $F(x)=S_{\text {loss }}$

$S_{\text {loss }}=\sum_{i=1}^{\text {bus.no bus.no }} \sum_{j=1}^{\text {bij }}\left(S_{i j}+S_{j i}\right)$

Nilai fungsi objektif yang dicari adalah nilai minimum, maka nilai fitness yang dicari harus nilai minimum fitness, dengan persamaan sebagai berikut:

Minimum Fitness $=\frac{1}{P_{\text {loss }}}$

Solusi dari setiap generasi mencari minimum fungsi objektif dan nilai terbesar dari fitness. Batasan-batasan yang digunakan adalah sebagai berikut:

- Batas Tegangan : [7]

$0,95 p u \leq\left|V_{i}\right| \leq 1,05 p u$

- Batas Faktor Daya :

$0,85 \leq P F \leq 1$

- Batas Kapasitor Shunt :

$Q c_{\text {min }} \leq Q c \leq Q c_{\text {max }}$

Diagram alur program optimasi dapat dilihat pada Gambar 8. 


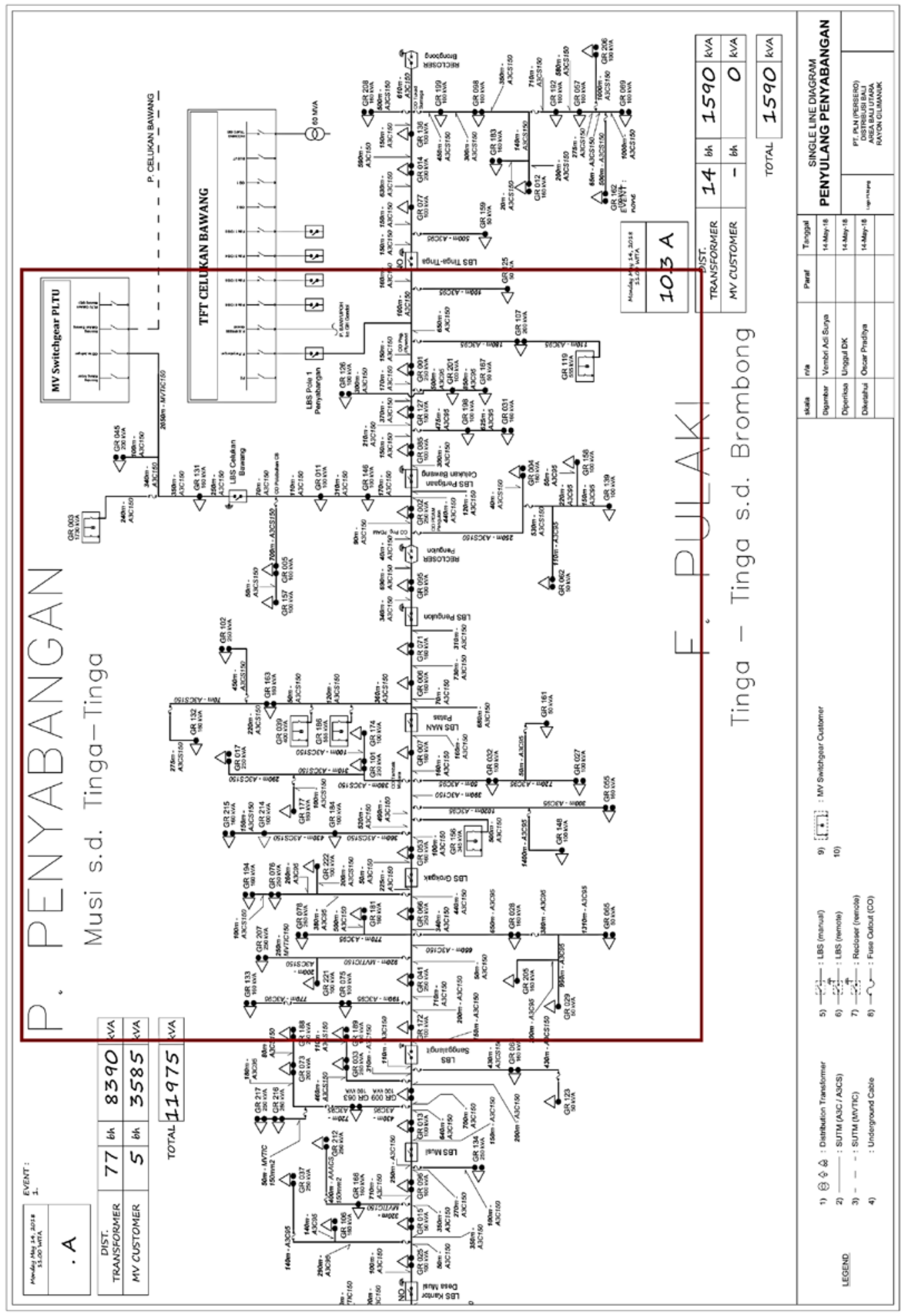

Gambar 7 Single Line Diagram Penyulang Penyabagan 


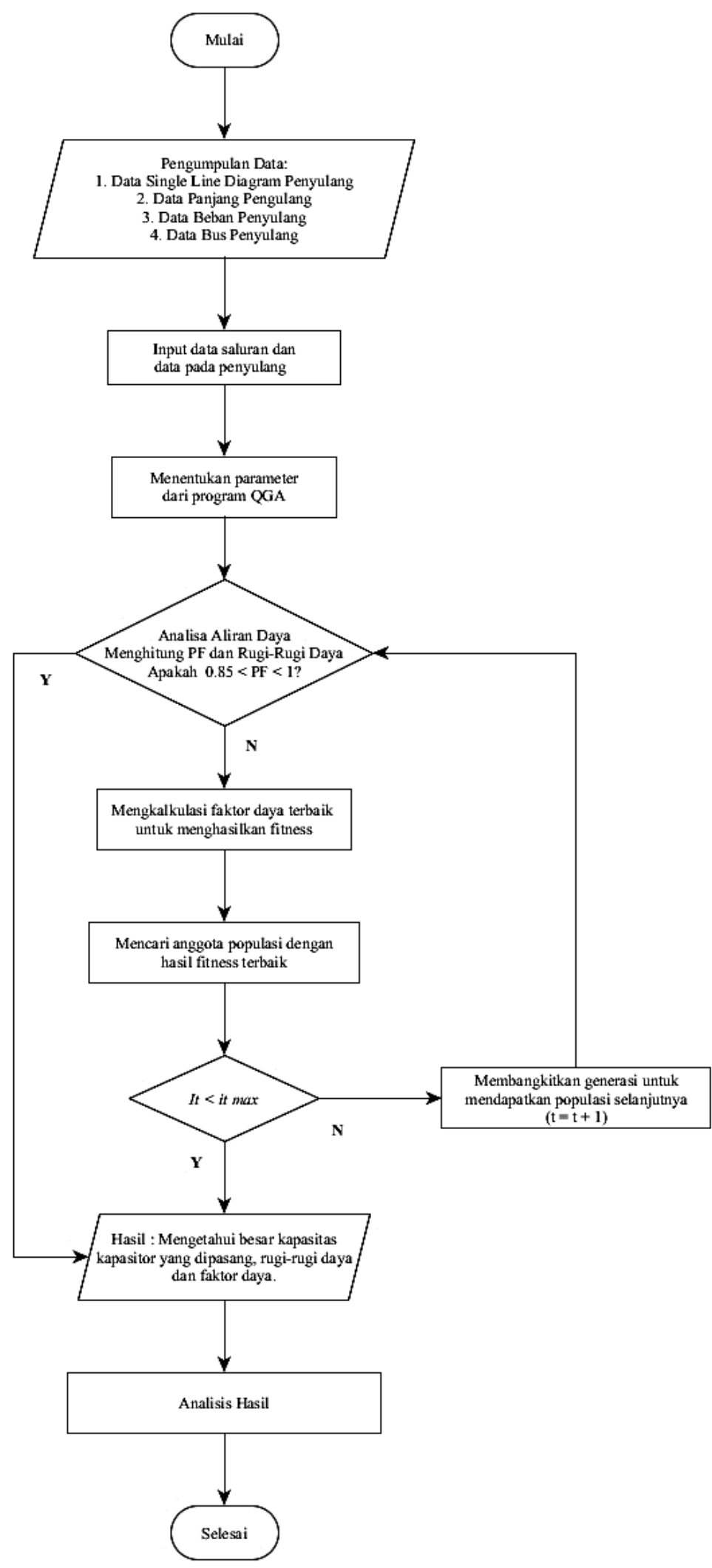

Gambar 8 Diagram Alur Program Optimasi 


\section{HASIL DAN PEMBAHASAN}

Penelitian ini menggunakan simulasi berbasis matlab. Parameter-parameter yang sudah diapatkan digunakan sebagai parameter input untuk analisa aliran daya dan menjalankan simulasi program optimasi pemasangan kapasitor dengan metode quantum genetic algorithm (QGA).

Program ini mencari bus berbeban yang memiliki faktor daya di luar batas yang diizinkan. Jika terdapat bus yang memiliki faktor daya di luar batas yang diizinkan, bus tersebut akan dipasang kapasitor. Perbaikan faktor daya diikuti dengan perbaikan total rugi-rugi daya pada jaringan tersebut.

\subsection{Hasil}

Program ini memberitahukan grafik tingkah laku dari quantum genetic algorithm. Grafik tingkah laku dari QGA dapat dilihat pada Gambar 9.

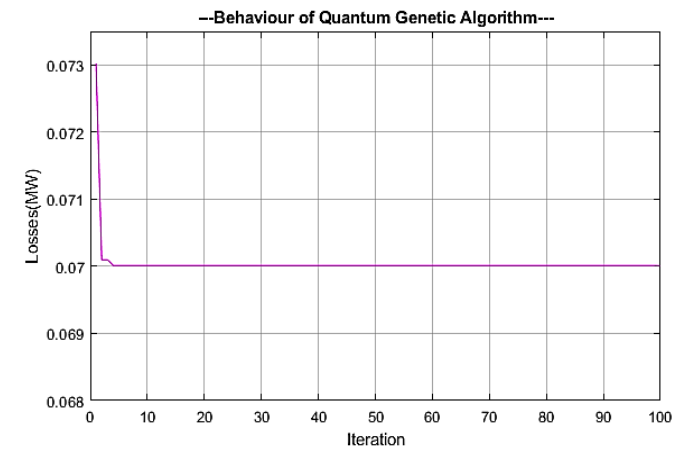

Gambar 9 Grafik Tingkah Laku Quantum Genetic Algorithm

Pada Gambar 9, dapat dilihat bahwa rugirugi daya mengalami penurunan. Hal ini disebabkan terdapat beberapa bus berbeban yang memiliki nilai faktor daya kurang dari batas yang diizinkan. Kemudian di setiap iterasi diperiksa dan dipasang kapasitor bank pada bus-bus tersebut sehingga total rugi-rugi daya berkurang. Total rugi-rugi daya sebelum optimasi pemasangan kapasitor dengan metode QGA memiliki total rugi-rugi daya sebesar 0,0674 MW dan 0,0546 MVAr. Setelah dijalankan simulasi program optimasi pemasangan kapasitor dengan metode QGA, total rugirugi daya menurun menjadi $0,0543 \mathrm{MW}$ dan 0,0442 MVAr.

Pada tabel 1, Setelah dilakukan optimasi pemasangan kapasitor dengan metode QGA, nilai faktor daya diperbaiki sehingga tidak ada bus yang memiliki nilai faktor daya diluar batas yang diizinkan.

Tabel 1 Nilai Faktor Daya Setelah Terpasang Kapasitor

\begin{tabular}{|c|c|c|c|c|c|}
\hline \multicolumn{2}{|r|}{ Bus } & \multirow{2}{*}{$\begin{array}{c}\text { Faktor Daya } \\
\text { Setelah } \\
\text { Terpasang } \\
\text { Kapasitor }\end{array}$} & \multicolumn{2}{|r|}{ Bus } & \multirow{2}{*}{\begin{tabular}{|c|} 
Faktor Daya \\
Setelah \\
Terpasang \\
Kapasitor
\end{tabular}} \\
\hline $\begin{array}{l}\text { No. } \\
\text { Bus }\end{array}$ & ID & & $\begin{array}{l}\text { No. } \\
\text { Bus }\end{array}$ & ID & \\
\hline 1 & $\begin{array}{l}\text { Bus GI } \\
\text { Pemaron }\end{array}$ & 0,952522 & 87 & Bus421 & 0,949174 \\
\hline 6 & Bus509 & 0,857493 & 91 & Bus478 & 0,999941 \\
\hline 9 & Bus507 & 0,855732 & 93 & Bus479 & 0,853796 \\
\hline 11 & Bus310 & 0,851171 & 95 & Bus482 & 0,850265 \\
\hline 13 & Bus440 & 0,988817 & 97 & Bus484 & 1.000000 \\
\hline 16 & Bus505 & 0,999934 & 99 & Bus473 & 0,851036 \\
\hline 18 & Bus311 & 0,999984 & 102 & Bus477 & 0,999438 \\
\hline 20 & Bus504 & 0,997252 & 103 & Bus476 & 0,850798 \\
\hline 22 & Bus437 & 0,998053 & 107 & Bus470 & 0,854199 \\
\hline 26 & Bus503 & 0,854199 & 109 & Bus471 & 0,850265 \\
\hline 27 & Bus314 & 0,857493 & 112 & Bus469 & 0,998835 \\
\hline 29 & Bus434 & 0,996614 & 115 & Bus333 & 0,857493 \\
\hline 33 & Bus444 & 0,992907 & 117 & Bus339 & 0,868243 \\
\hline 35 & Bus446 & 0,998164 & 119 & Bus341 & 0,997252 \\
\hline 38 & Bus499 & 0,999557 & 121 & Bus415 & 0,963270 \\
\hline 40 & Bus501 & 0,998835 & 126 & Bus345 & 0,868243 \\
\hline 43 & Bus449 & 0,851658 & 128 & Bus468 & 0,852601 \\
\hline 46 & Bus320 & 0,997800 & 130 & Bus348 & 0,998246 \\
\hline 49 & Bus502 & 0,999814 & 132 & Bus412 & 0,999987 \\
\hline 52 & Bus431 & 0,850265 & 137 & Bus356 & 0,850265 \\
\hline 55 & Bus492 & 0,857493 & 139 & Bus460 & 0,986639 \\
\hline 58 & Bus493 & 0,850265 & 141 & Bus462 & 0,850798 \\
\hline 60 & Bus497 & 0,992907 & 144 & Bus350 & 0,983153 \\
\hline 62 & Bus498 & 0,993468 & 146 & Bus466 & 1.000000 \\
\hline 65 & Bus428 & 0,972548 & 148 & Bus467 & 0,964685 \\
\hline 68 & Bus426 & 0,999963 & 152 & Bus359 & 0,868243 \\
\hline 70 & Bus424 & 0,853282 & 154 & Bus1190 & 0,850798 \\
\hline 73 & Bus309 & 0,999997 & 156 & Bus408 & 0,851658 \\
\hline 75 & Bus487 & 0,850707 & 159 & Bus456 & 0,851658 \\
\hline 77 & Bus324 & 0,999983 & 161 & Bus458 & 0,851036 \\
\hline 80 & Bus488 & 0,850265 & 163 & Bus404 & 0,852601 \\
\hline 84 & Bus490 & 0,852601 & & & \\
\hline
\end{tabular}

Pada tabel 2, dapat dilihat lokasi dan kapasitas kapasitor yang terpasang. Dari total bus berbeban sebanyak 62 bus, dibutuhkan pemasangan kapasitor di 29 bus berbeban dengan kapasitas yang dibutuhkan sesuai dengan tabel 2. Dengan dipasang kapasitor pada bus-bus tersebut, kapasitor shunt memberikan arus reaktif untuk mengimbangi arus yang diambil oleh beban induktif.

Tabel 2 Lokasi dan Kapasitas Kapasitor yang Terpasang

\begin{tabular}{|c|c|c|c|c|c|}
\hline \multicolumn{2}{|c|}{ Bus } & $\begin{array}{c}\text { Kapasitas } \\
\text { Kapasitor } \\
\text { (Mvar) }\end{array}$ & \multicolumn{2}{c|}{ Bus } & $\begin{array}{c}\text { Kapasitas } \\
\text { Kapasitor } \\
\text { (Mvar) }\end{array}$ \\
\hline $\begin{array}{c}\text { No. } \\
\text { Bus }\end{array}$ & ID & $\begin{array}{c}\text { Setelah } \\
\text { Terpasang } \\
\text { Kapasitor }\end{array}$ & No. Bus & ID & $\begin{array}{c}\text { Setelah } \\
\text { Terpasang } \\
\text { Kapasitor }\end{array}$ \\
\hline $\mathbf{1 3}$ & Bus440 & 0,021 & $\mathbf{6 8}$ & Bus426 & 0,046 \\
\hline $\mathbf{1 6}$ & Bus505 & 0,012 & $\mathbf{7 3}$ & Bus309 & 0,231 \\
\hline $\mathbf{1 8}$ & Bus311 & 0,023 & $\mathbf{7 7}$ & Bus324 & 0,03 \\
\hline $\mathbf{2 0}$ & Bus504 & 0,008 & $\mathbf{8 7}$ & Bus421 & 0,012 \\
\hline $\mathbf{2 2}$ & Bus437 & 0,027 & $\mathbf{9 1}$ & Bus478 & 0,066 \\
\hline $\mathbf{2 9}$ & Bus434 & 0,023 & $\mathbf{1 0 2}$ & Bus477 & 0,019 \\
\hline $\mathbf{3 3}$ & Bus444 & 0,003 & $\mathbf{1 1 2}$ & Bus469 & 0,01 \\
\hline $\mathbf{3 5}$ & Bus446 & 0,015 & $\mathbf{1 1 9}$ & Bus341 & 0,008 \\
\hline
\end{tabular}




\begin{tabular}{|l|l|c|c|l|c|}
\hline $\mathbf{3 8}$ & Bus499 & 0,009 & $\mathbf{1 2 1}$ & Bus415 & 0,01 \\
\hline $\mathbf{4 0}$ & Bus501 & 0,01 & $\mathbf{1 3 0}$ & Bus348 & 0,007 \\
\hline $\mathbf{4 6}$ & Bus320 & 0,041 & $\mathbf{1 3 2}$ & Bus412 & 0,06 \\
\hline $\mathbf{4 9}$ & Bus502 & 0,03 & $\mathbf{1 3 9}$ & Bus460 & 0,04 \\
\hline $\mathbf{6 0}$ & Bus497 & 0,005 & $\mathbf{1 4 4}$ & Bus350 & 0,006 \\
\hline $\mathbf{6 2}$ & Bus498 & 0,005 & 148 & Bus467 & 0,009 \\
\hline $\mathbf{6 5}$ & Bus428 & 0,015 & & & \\
\hline
\end{tabular}

4 SIMPULAN DAN SARAN

4.1 Simpulan

Berdasarkan hasil penelitian dan pembahasan yang telah dilakukan, maka dapat dikemukakan kesimpulan dari penelitian ini sebagai berikut di bawah ini.

1. Setelah dilakukan optimasi pemasangan kapasitor dengan metode QGA, tidak terdapat bus yang memiliki nilai faktor daya diluar batas yang diizinkan. Perubahan nilai faktor daya dari sebelum dan setelah optimasi pemasangan kapasitor dapat dilihat pada tabel 1.

2. Setelah dilakukan optimasi pemasangan kapasitor dengan metode QGA, total rugirugi daya menurun dari sebesar 0,0674 MW dan 0,0546 MVAr menjadi 0,0543 MW dan 0,0442 MVAr.

3. Setelah dilakukan optimasi pemasangan kapasitor dengan metode QGA, kapasitor terpasang pada 29 bus dengan kapasitas kapasitor yang digunakan berbeda-beda. Lokasi dan besar kapasitas kapasitor yang terpasang dapat dilihat pada tabel 2.

\subsection{Saran}

Saran yang dapat disampaikan dari penelitian ini adalah untuk penelitian selanjutnya dapat mengembangkan sistem ini seperti dengan memperhitungkan faktor ekonomis dan faktor harmonisa akibat penambahan kapasitor bank tersebut.

\section{DAFTAR PUSTAKA}

[1] Habsoro Sigit Wisnu, dkk, Analisa Penempatan Kapasitor Bank untuk Perhitungan Drop Voltage Pada Feeder Batang 02 Tahun 2012-2016 dengan Software ETAP 7.0.0,TRANSIENT, 2013, VOL.2, hal 1.

[2] Syahputra Dr. Ramadoni. Transmisi dan Distribusi Tenaga Listrik, Yogyakarta : LP3M UMY Yogyakarta. 2017:130-132

[3] Rahmaan Aulia Bagus Ar, dkk. Optimalisasi Penempatan Kapasitor Bank untuk Memperbaiki Kualitas Daya Pada Sistem Kelistrikan PT. Semen Indonesia
Aceh Menggunkan Metode Genetic Algorithm (GA), Jurnal Teknik ITS Vol.5. 2016:B230-B231.

[4] Shafira Andita Noor, dkk. Penentuan Letak dan Kapasitas Optimal Bank Kapasitor pada Jaringan Transmisi 150 kV Sumatera Utara Menggunakan Artificial Bee Colony Algorithm, Jurnal Teknik ITS Vol.5. 2016 : A752.

[5] Bandri Sepanur, Topan Danial. Studi Analisa Pemasangan Kapasitor Pada Jaringan Udara Tegangan Menengah 20 kV Terhadap Drop Tegangan (Aplikasi pada Feeder 7 Pinang GI Muaro Bungo), Jurnal Teknik Mesin Vol.4, No1. 2014 : 32-33.

[6] PT. PLN (PERSERO). Buku Pedoman Pemeliharaan Kapasitor. Jakarta : PT. PLN (Persero) No. 0520-2.K/DIR/2014. $2014: 2-3$.

[7] Manurung Chandra Wimartono, dkk. Optimasi Pemasangan dan Kapasitas Kapasitor Shunt Pada Jaringan Penjulang Menjangan. Jurnal Teknologi Elektro, Vol.16. $2017: 8$.

[8] Stevenson William D. Analisis Sistem Tenaga Listrik. Jakarta : Penerbit Erlangga. 1984 : 215-217.

[9] Aryani Ni Ketut, dkk. Optimal Placement and Sizing of Distributed Generation Algorithm for Reducing Losses and Improving Voltage Profile, TENCON, 2011, hal 109.

[10]Fan xin, dkk. Network Optimization Method Based on Improved Quantum Genetic Algorithm, Fourth International Symposium on Information Science and Engineering, 2012, hal 423. 